\title{
PENERAPAN LOCATION BASED SERVICE UNTUK OPTIMASI SISTEM INFORMASI GEOGRAFIS PONDOK PESANTREN WILAYAH TEGAL
}

\author{
Oman Somantri ${ }^{1}$, Rosid Mustofa ${ }^{2}$, Mukhamad Faujan ${ }^{3}$ \\ 1,2,3 Jurusan Teknik Informatika, Politeknik Harapan Bersama Tegal \\ JIn. Mataram No.09 Pesurungan Lor Tegal, Indonesia \\ 1'oman_mantri@yahoo.com, ${ }^{2} x$ rosid@gmail.com, ${ }^{3}$ mukhamadfauzan09@gmail.com
}

\begin{abstract}
Abstrak-Kota Tegal dan sekitarnya mempunyai beberapa pondok pesantren yang keberadaannya mayoritas tersebar di daerah-daerah pedesaaan, namun informasi mengenai lokasi serta informasi yang ada pada pondok pesantren masih terbatas. Dengan demikian dibutuhkan sistem yang mampu memberikan sebuah solusi yang dapat menunjukan keberadaan lokasi serta informasi lain pada pondok pesantren. Sistem informasi geografis berbasis mobile dihadirkan untuk memberikan solusi dari permsalahan yang ada. Perancangan dalam pembuatan sistem ini menggunakan Unified Modeling Language (UML) dan dibangun dengan menggunakan android studio dengan MySQL sebagai database. Hasil dari perancangan sistem ini adalah sebuah sistem informasi geografis pondok pesantren wilayah Tegal dan sekitarnya berbasis mobile yang dapat diimplementasikan untuk memberikan informasi letak lokasi pondok pesantren beserta informasi-informasi yang ada pada pondok pesantren tersebut.
\end{abstract}

Keywords — pondok pesantren, sistem informasi geografis, android

\section{PENDAHULUAN}

Sebagai negara yang mayoritas penduduk muslim keberadaaan pondok pesantren di Indonesia saat ini sangat banyak jumlahnya. Pondok pesantren merupakan sebuah lembaga pendidikan dimana didalam lembaga tersebut dipelajari ilmu-ilmu mengenai keagamaan terutama agama Islam. Dalam perkembangannya pondok pesantren mengalami kemajuan tidak hanya mempelajari ilmu agama saja melainkan ilmu-ilmu pengetahuan umum dan teknologi di tempat lembaga tersebut. Pondok pesantren mempunyai peranan dalam perkembangan masyarakat pada segi sosial budaya untuk menghadapi perkembangan zaman sekarang yang sudah berada pada tingkat perkembangan teknologi baik itu ilmu pengetahuan maupun produk hasil dari teknologi tersebut yang semakin maju saat ini.

Tegal yang saat ini terbagi menjadi dua bagain yaitu wilayah Kota dan Kabupaten, merupakan salah satu wilayah yang berada di Jawa Tengah yang mempunyai beberapa pondok pesantren yang keberadaannya mayoritas tersebar di seluruh pelosok pedesaan. Berdasarkan data Kantor Kementrian Agama Kota Tegal dan Kabupaten Tegal pada tahun 2016 saja saat itu jumlah pondok pesantren yang berada di wilayah Tegal berjumlah 55 pondok pesantren. Kota Tegal mempunyai 11 pondok pesantren dan Kabupaten Tegal yang paling banyak yaitu sekitar 44 pondok pesantren. Karena banyaknya jumlah pondok pesantren tersebut dengan informasi yang berbeda-beda, masyarakat merasa masih mempunyai kesulitan dalam mencari informasi terkait dengan pondok pesantren tersebut secara detail.
Permasalahan lain adalah banyak masyarakat yang belum mengetahui lokasi wilayah tempat pondok pesantren wilayah Tegal tersebut berada.

Berdasarkan permasalahan yang dihadapi maka perlu adanya sebuah solusi yang dapat mengatasi permasalahan tersebut, salah satu solusi yang dapat dilakukan adalah dengan dibuatnya sebuah sistem informasi yang berbasis informasi teknologi yang mampu memberikan informasi secara detail terakait dengan pondok pesantren tersebut dan mampu menunjukan lokasi pondok pesantren tersebut beserta informasi yang detail. Sistem Informasi Geografis (SIG) merupakan sistem yang mempunyai kemampuan yang sangat luas baik dalam proses pemetaan maupun analisis sehingga teknologi tersebut sering digunakan dalam proses perencanaan tata ruang [1]. Kemampuan ini sama halnya dengan sebuah sistem informasi yang berkembang sekarang menggunakan konsep Service Oriented Architecthure (SOA) dewasa ini [2].

Smartphone merupakan sebuah produk dari pengembangan teknologi yang dikembangkan untuk dapat lebih memudahkan orang dalam melakukan berbagai hal. Teknologi ini digunakan selain sebagai alat komunikasi, seiring perkembangan zaman digunakan pula sebagai alat transaksi melalui berbagai macam aplikasi yang berbasiskan android [3]. Location Based Service (LBS) merupakan sebuah layanan yang konsepnya adalah berbasis lokasi, layanan informasi ini dapat digunakan untuk diakses melalui mobile device seperti smartphone dengan menggunakan sistem mobile network, layanan ini dilengkapi dengan kemampuan untuk memanfaatkan lokasi dari mobile device yang ada. LBS merupakan penggabungan dari beberapa teknologi seperti 
Geographic Information Service (GIS), Mobile Device, dan Internet Service[4]. Wu, et all (2015) [5] dalam penelitiannya memberikan gambaran penerapan aplikasi mobile yang menampilkan peta dalam sebuah kampus. Dengan kemampuan antara smartphone dan LBS maka pengembangan sebuah sistem dengan menggunakan konsep tersebut dapat memudahkan setiap orang dalam mengetahui letak sebuah titik posisi, disamping itu melalui layanan Google maps maka integrasi dari sistem tersebut dapat lebih optimal. Bentuk implementasi LBS biasanya dalam bentuk mobile navigation, iklan berbasis lokasi dan layanan check-in jaringan sosial seluler serta emergency tracking[6].

Terdapat beberapa penelitian terdahulu terkait penelitian yang dilakukan, seperti yang dilakukan oleh Mohammad (2014) meneliti terkait dengan sistem informasi geografis pondok pesantren di Kota Rembang berbasis android [7]. Selain terkait dengan pondok pesantren, penelitian terkait dengan GIS dilakukan juga oleh Yunanada et all (2015) [8] melakukan penelitian dengan pembuatan sistem informasi geografis pelayanan kesehatan di Kota Palembang, pada penelitian ini menghasilkan aplikasi android yang memberikan pilihan rute yang dapat digunakan pengguna untuk mencapai lokasi layanan kesehatan di kota palembang yang dituju. Pradana, (2016) [9] membuat sebuah sistem informasi geografis berbasis mobile dengan memanfaatkan Google maps yang digunakan oleh para wisatawan dalam memperoleh informasi seperti informasi jalan dan lokasi wisata yang ada di wilayah ASEAN..

Berdasarkan penelitian sebelumnya, pada penelitian ini diterapkan Location Based Service dengan integrasi Google Maps untuk mengoptimalisasi pemetaan pondok pesantren di wilayah Kota Tegal. Tujuan dari penelitian ini adalah membangun sebuah sistem informasi geografis untuk pemetaan pondok pesantern wilayah tegal dengan menerapkan Location Based Service (LBS) dan Google Maps untuk mengoptimalisasi pemetaan tata letak pondok pesantren di wilayah Tegal dan sekitarnya sehingga dapat membantu masyarakat dalam mengetahui lokasi pondok pesantren serta informasi lain secara detail terhadap pondok pesantren tersebut.

\section{METODE PENELITIAN}

\section{A. Dataset Penelitian}

Data yang digunakan untuk penelitian ini adalah data terkait dengan informasi pondok pesantren di wilayah Tegal baik itu Kota maupun Kabupaten Tegal yang diambil di Kantor Kementrian Agama kota dan Kabupaten Tegal pada tahun 2017. Data diambil melalui wawancara dan observasi langsung ke beberapa pondok pesantren di wilayah Tegal untuk dijadikan sebagai data pendukung penelitian.

\section{B. Desain dan Perncangan System}

Untuk merancang bangun sistem infomasi geografis dengan menerapkan Location Base Service (LBS) pada tahapan ini dilakukan beberapa terkait dengan tahapan desain dan rancangan sistem yang dibuat [6], [10], [11]. Pada proses tahapan penelitian dilakukan dengan melalui tahapan analisis masalah, pengumpulan data penelitian, perancangan dan desain sistem, pembuatan sistem dan yang paling tidak bisa dihilangkan adakan test usability sistem dalam hal ini menggunakan black box.diantaranya yaitu:

1) Analisis Masalah:Pada tahapan ini proses analisis dilakukan untuk memperoleh sebuah gambaran terkait dengan permasalahan yang diteliti. Objek penelitian adalah pondok pesantren diseluruh wilayah Tegal

2) Pengembangan Sistem: Pada tahapan ini dilakukan proses desain dari sistem informasi Geografis yang dibangun, yaitu dengan menggunakan metode Unified Modeling Language (UML). Perncangan sistem yang dibuat adalah use case diagram, activity diagram, sequence diagram, dan class diagram.

3) Pembuatan Sistem: Pada pembanguann sistem yang telah dirancang, pada tahapan ini sistem dibangun dengan menggunakan bahasa pemrograman java berbasis android. Tools yang digunakan adalah android studio dengan MySQI sebagai database yang digunakan.

4) Evaluasi Sistem: Untuk memperoleh sistem yang diinginkan, usability sistem dilakukan dengan menggunakan metode black box, metode ini merupakan cara untuk mengetahui tingkat keberhasilan setiap fungsi dari sistem yang dibuat sehingga sesuai dengan yang diinginkan dari perencanaan sebelumnya.

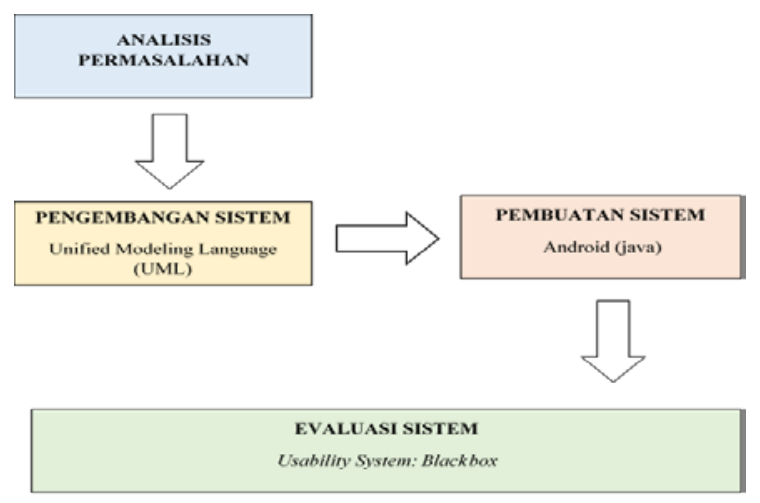

Gbr. 1 Tahapan Penelitian Yang Diusulkan

Pada Gbr 1 merupakan tahapan penelitian yang diusulkan pada penelitian ini, tahapan tersebut terdiri dari analisis permasalahan, pengembnagan sistem, pembuatan sistem dan evaluasi sistem. 


\section{HASIL DAN PEMBAHASAN}

\section{A. Use Case Diagram}

Tahapan pertama dalam membangun desain sistem yang dilakukan adalah dengan membuat use case diagram. Diagram ini memperlihatkan

Page|108 bagaimana interaksi actor sesuai dengan fungsinya pada sistem yang dibuat, diperlihatkan pada Gbr 2.

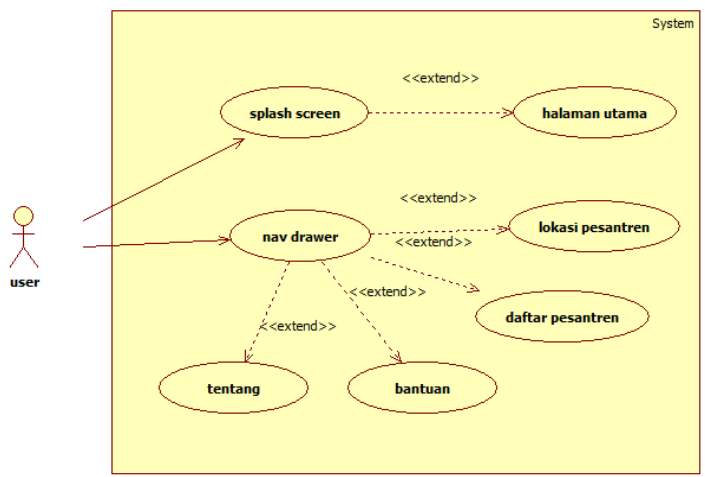

Gbr. 2 Use Case Diagram Sistem

Pada Gbr 2 memperlihatkan bahwa jumlah actor yang telibat adalah satu, sebagai user. Actor mempunyai fungsi dimana ketika user membuka aplikasi maka sistem akan menampilkan proses splash screen sebelum masuk ke halaman utama, setelah itu pada halaman menu utama terdapat pilihan nav drawer yang nantinya terdapt beberapa menu aplikasi seperti "lokasi pesantren”, “daftar pesantren”, "bantuan”

\section{B. Activity Diagram}

Tahapan selanjutnya adalah membuat desain sistem untuk activity diagram, pada diagram ini menggambarkan sebuah aktifitas yang dilakukan oleh user. Salah satu bagian activity diagram pada Gbr 3 merupakan visualisasi dari aktifitas proses daftar pesantren.

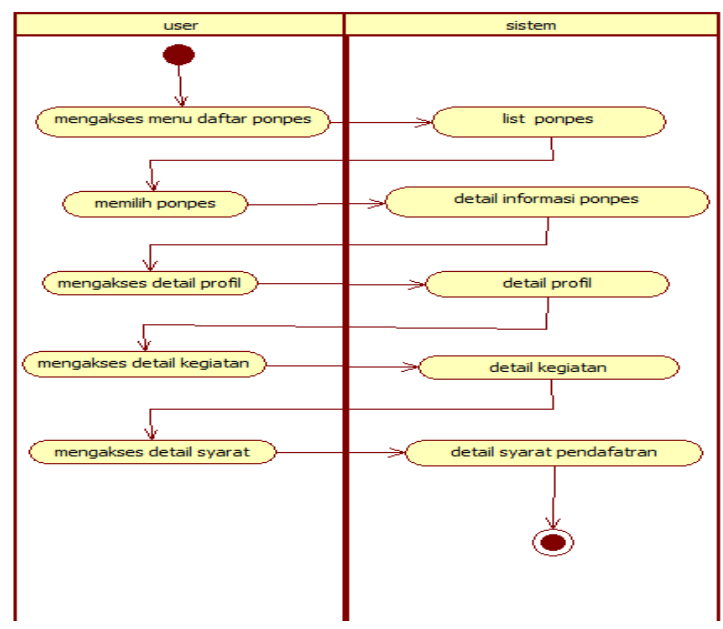

Gbr. 3 Activity Diagram Daftar Pesantren

\section{Sequence Diagram}

Untuk desain sequence diagram pada sistem informasi geografis pondok pesantren wilayah Tegal seperti pada Gbr 4.

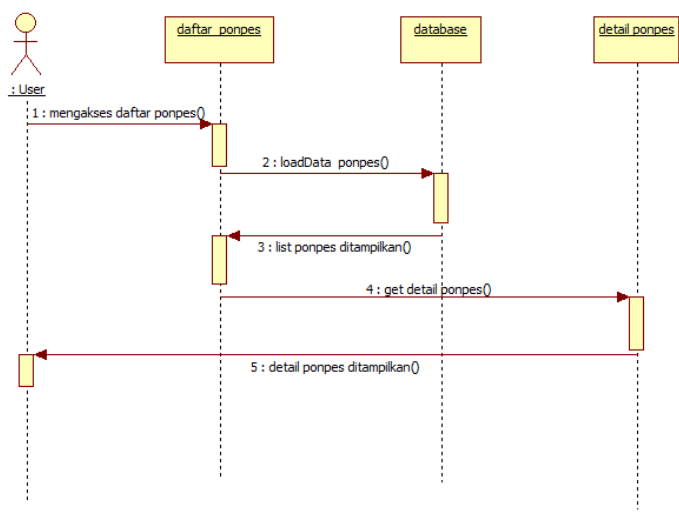

Gbr. 4 Sequence Diagram Daftar Pesantren

\section{Class Diagram}

Tahapan selanjutnya adalah pembuatan class diagram, model yang dibuat merupakan refresentasi dari perencanaan pembangunan sistem yang terdiri dari class-class yang dimodelkan.

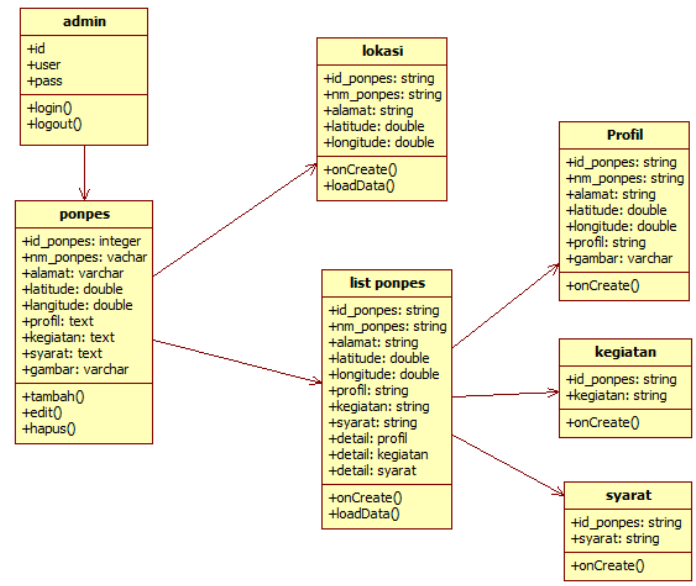

Gbr. 5 Class Diagram Sistem

Pada Gbr 5 merupakan desain dari class diagram sistem informasi geografis pondok pesantren. Jumlah pada desain class diagram terdiri dari 6 class, yaitu admin, ponpes, lokasi, list ponpes, profil, kegiatan dan class syarat.

\section{E. Judul dan Penulis}

Dalam perancangan database sistem informasi geografis pondok pesantren wilayah Tegal perancangan database tersebut seperti pada Tabel 1. 
TABEL 1

RANCANGAN DATABASE SISTEM SIG

Page | 109

\begin{tabular}{|l|l|l|}
\hline \multicolumn{1}{|c|}{ Field } & \multicolumn{1}{c|}{ Type } & Keterangan \\
\hline id_ponpes & $\operatorname{Int}(11)$ & Primary Key \\
\hline nm_ponpes & Varchar(50) & \\
\hline alamat & Varchar(50) & \\
\hline latitude & Double & \\
\hline longitude & Double & \\
\hline profil & Text & \\
\hline kegiatan & Text & \\
\hline syarat & Text & \\
\hline gambar & Varchar(50) & \\
\hline
\end{tabular}

\section{F. Implementsi Sistem}

1) Interface Halaman Splash Screen: Tampilan halaman splash screen merupakan tampilan interface yang pertama kali muncul pada saat user membuka aplikasi sistem informasi geografis pondok pesantren sebelum masuk kepada halaman utama, diperlihatkan pada Gbr 6.

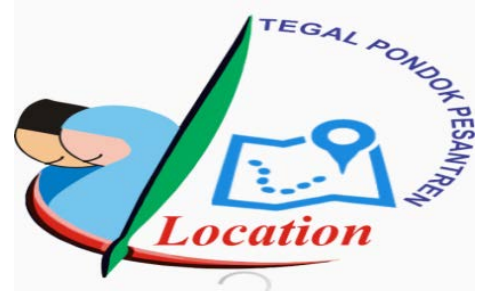

Gbr. 6 Tampilan Interface Halaman Splash Screen

2) Interface Halaman Utama SIG: Halaman utama akan tampil setelah proses splash screen selesai. Pada tampilan ini terdapat gambar dalam bentuk slider tentang pondok pesantren, seperti pada Gbr 7.

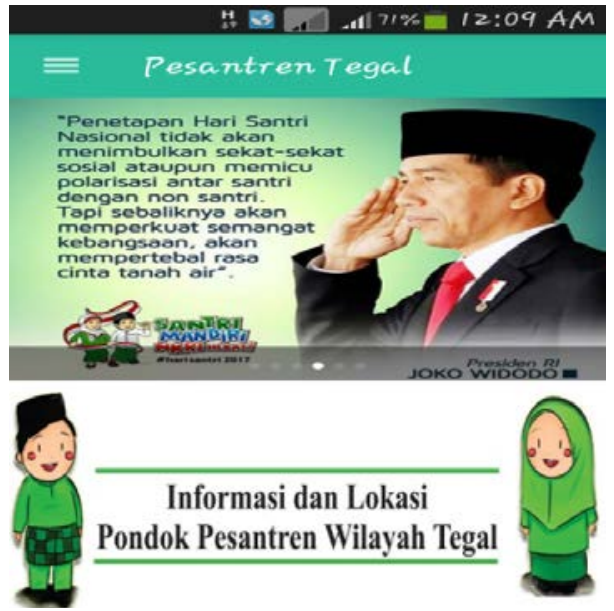

Gbr. 7 Tampilan Interface Halaman Utama
3) Interface Halaman List Menu: Halaman ini menampilkan menu pada aplikasi menggunakan tampilan navigation drawer, diperlihatkan pada Gbr 8.

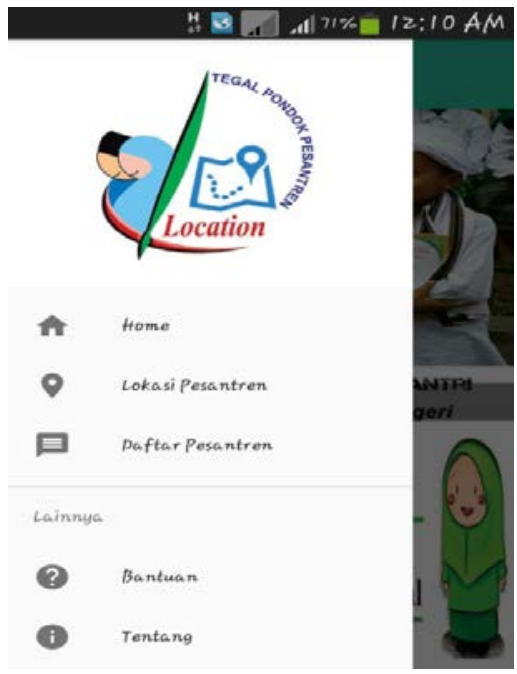

Gbr. 8 Tampilan Interface Halaman List Menu

4) Interface Halaman Lokasi Pesantren: Halaman lokasi pesantren untuk menampilkan semua marker pesantren yang terdapat di Wilayah Tegal, pada Gbr 9.

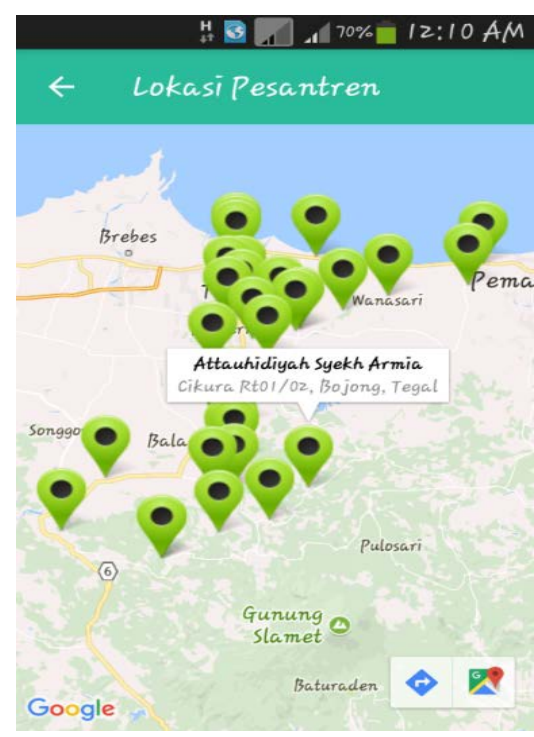

Gbr. 9 Tampilan Interface Halaman Lokasi Pesantren

5) InterfaceHalaman Detail Pesantren: Halaman ini berisi tentang informasi-informasi yang terdapat pada pondok pesantren, dan terdapat beberapa pilihan seperti menu profil yang menampilkan informasi profil pesantren, menu kegiatan yang menampilkan informasi kegiatan pesantren dan menu lainnya yang menampilkan informasi pendaftaran santri baru serta rincian biaya pesantren, diperlihatkan pada Gbr 10. 

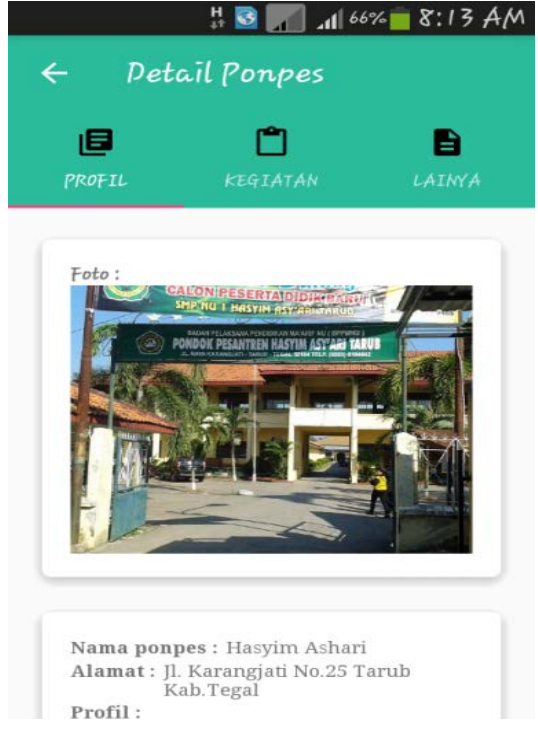

Gbr. 10 Tampilan Interface Halaman Detail Pesantren

\section{G. Evaluasi dan Uji Sistem}

Untuk melihat sejauhmana keberhasiln dalam pembangunan sistem informasi pondok pesantren dengan menerapkan Location Base Service (LBS) dan Google Maps, maka untuk pengujian sistem sebagai usability sistem menggunakan metode black box. Metode black box digunakan untuk melihat sejauh mana tingkat kebrhasilan fungsional setiap sub sistem yang terdapat dalam sistem tersebut, diperlihatkan pada Tabel II.

TABEL I

RANCANGAN DATABASE SISTEM SIG

\begin{tabular}{|c|c|c|c|}
\hline \multirow{2}{*}{ No } & \multicolumn{3}{|c|}{ Test Procedure } \\
\hline & Verify that & Test Description & Result \\
\hline 1 & $\begin{array}{l}\text { Halaman Splash } \\
\text { Screen }\end{array}$ & $\begin{array}{l}\text { Pengecekan proses } \\
\text { open aplikasi } \\
\text { pertama kali }\end{array}$ & Success \\
\hline 2 & Halaman Utama & $\begin{array}{l}\text { Cek tampilan } \\
\text { halaman utama } \\
\text { beserta komposisi } \\
\text { halaman utama }\end{array}$ & Success \\
\hline 3 & $\begin{array}{l}\text { Halaman } \\
\text { Lokasi } \\
\text { Pesantren }\end{array}$ & $\begin{array}{l}\text { Pengecekan proses } \\
\text { tata letak dan } \\
\text { kesesuaian posisi } \\
\text { lokasi pada peta } \\
\text { map }\end{array}$ & Success \\
\hline 4 & $\begin{array}{l}\text { Halaman Dfatar } \\
\text { Pesantren }\end{array}$ & $\begin{array}{l}\text { Pengecekn daftar } \\
\text { pesantren dan isi } \\
\text { konten informasi } \\
\text { setaip pesantren }\end{array}$ & Success \\
\hline 5 & $\begin{array}{l}\text { Halaman } \\
\text { bantuan }\end{array}$ & $\begin{array}{l}\text { Pengecekan } \\
\text { informasi dan tata } \\
\text { letak inteface } \\
\text { bantuan }\end{array}$ & Success \\
\hline 6 & $\begin{array}{l}\text { Halaman } \\
\text { tentang }\end{array}$ & $\begin{array}{l}\text { Pengecekan } \\
\text { informasi dan tata } \\
\text { letak inteface menu } \\
\text { tentang }\end{array}$ & Success \\
\hline
\end{tabular}

\section{PENUTUP}

Berdasarkan hasil penelitian memperlihatkan bahwa penerapan Google Maps yang terintegrasi dengan Location Based Service (LBS) pada sistem informasi geografis untuk pemetaan pondok pesantren wilayah kota tegal memberikan hasil rancang bangun yang optimal sehingga siap utnuk diimplementasikan. Untuk penelitian selanjutnya adalah perlu adanya sebuah optimalisasi dengan menerapkan sebuah kecerdasan buatan pada sistem informasi geografis berbasis android ini, sehingga sistem yang dibuat menjadi lebih pintar dan lebih baik. Dari Segi keamananpun [12] untuk penelitian selanjutnya bisa menjadi prioritas utama, hal ini dilakukan karena keamanan data sekarang ini menjadi prioritas.

\section{REFERENSI}

[1] Rahman, "Pendidikan Agama Islam Dan Pendidikan Islam Tinjauan Epistemologi Dan Isi - Materi,” J. Eksis, vol. 8, no. 1, pp. 2053-2059, 2012.

[2] O. Somantri and I. D. Hasta, “Implementasi e-Government Pada Kelurahan Pesurungan Lor Kota Tegal Berbasis Service Oriented Architecture (SOA),” J. Inform. Pengemb. IT, vol. 2, no. 1, 2017.

[3] N. Ahmad, A. Rextin, and U. E. Kulsoom, "Perspectives on usability guidelines for smartphone applications: An empirical investigation and systematic literature review," Inf. Softw. Technol., vol. 94, pp. 130-149, 2018.

[4] N. Safaat, Rancang Bangun Aplikasi Multiplatform. Bandung: Informatika, 2015.

[5] F. Wu, D. Clarke, J. Jiang, A. Baba, and S. Buford, "The Digital Age of Campus Maps on Mobile Devices,” no. May, pp. 22-30, 2016.

[6] T. Zhou, "The impact of privacy concern on user adoption of location-based services,” Ind. Manag. Data Syst., vol. 111, no. 2, pp. 212-226, 2011.

[7] M. Vieky Toyibah and D. P. Kusumaningrum, "Sistem Informasi Geografis Pondok Pesantren Di Kota Rembang Berbasis Android,” Fakultas Ilmu Komputer, Universitas Dian Nuswantoro, 2015

[8] Y. Yunanda, M. H. Ruba'i, A. Farisi, and D. Udjulawa, "Sistem informasi geografis pelayanan kesehatan dikota palembang,” STMIK GI MDP Palembang, 2016.

[9] D. W. Pradana and R. Kurniawan, "Sentras (Asean Tourist Attractions) : Gis Application For Optimizing Asean Tourism Using Google Maps Api V2 Based On Android Operating System,” no. 2010, pp. 318-323, 2016

[10] S. Hin, "Consumer Personality, Privacy Concerns and Usage of Location-Based Services (LBS),” J. Econ. Bus. Manag., vol. 3, no. 10, 2015.

[11] A. Basiri, E. S. Lohan, T. Moore, A. Winstanley, P. Peltola, C. Hill, P. Amirian, and P. Figueiredo e Silva, "Indoor location based services challenges, requirements and usability of current solutions,” Comput. Sci. Rev., vol. 24, pp. 1-12,

[12] J. Lin, J. Niu, H. Li, and M. Atiquzzaman, "A Secure and Efficient Location-based Service scheme for smart transportation,” Futur. Gener. Comput. Syst., 2017 